\title{
Шандор Бонкало - дослідник української мови, діалектології та літератури
}

\author{
ЄЛИЗАВЕТА БАРАНЬ \\ II. Rákóczi Ferenc Kárpátaljai Magyar Főiskola, UA-90202 Beregszász, Kossuth tér 6. \\ BÁRÁNY Erzsébet, Ferenc Rákóczi II. Transcarpathian Hungarian Institute \\ E-mail: barany.erzsebet75@gmail.com
}

(Received: 4 November 2017; accepted: 11 February 2018)

\begin{abstract}
The aim of the present paper is to describe Sándor Bonkáló's research in the field of Ukrainian language and dialectology, to emphasize the importance of his approach to the definition of the place of Ukrainian among other East Slavic languages, to outline the characteristic features of Bonkáló's investigations in the field of Hutsul dialects and ethnography as well as to focus on the role of Bonkáló's research in the development of Carpathian Ruthenian literature and culture.
\end{abstract}

Keywords: Sándor Bonkáló, Ukrainian language, Ukrainian dialectology, Hutsul dialects and ethnography, Carpathian Ruthenian literature

У статті маємо на меті проаналізувати діяльність Шандора Бонкала у дослідженні української мови та діалектології, визначити його науковий підхід щодо визначення місця української мови серед інших східнослов'янських мов, окреслити основні штрихи діяльності науковця у сфері гуцульської діалектології та етнографії, розглянути дослідженння науковця у галузі закарпатської української літератури і культури.

Шандор (Олександр) Бонкало (угорською: Bonkáló Sándor) (псевдонім О. Рахівський) народився 22 січня 1880 року в Рахові (історична Мараморощина), місто на той час входило до складу Угорського королівства (про його діяльність див. Поп 2001: 101-102, ГеРАсимовА 2003: 338). Бонкало навчався в Ужгородській гімназії та духовній семінарії, оскільки в багатьох грекокатолицьких сім'ях прийнято було віддавати старшого сина в священики (BoNKÁLÓ 1996: 7). Відтак продовжив навчання в Будапештському, Лейпцігському та Санкт-Петербурзькому університетах. У 1906 році закінчив латинське, німецьке і слов'янське відділення Будапештського університету ім. Петера Пазманя. Він був учнем відомих славістів - Оскара Ашбота, Олександра Шахматова, Яна Бодуена де Куртене. Із 1905 по 1916 рік працював шкільним учителем у різних містах Угорщини (Сегед, Дьондьош, Залаегерсег). Різнобічна діяльність Шандора Бонкала висвітлена в дисертації Аттіли Шалги (див. SALGA 1975).

У 1919 році в Будапештському університеті створено кафедру русинської мови та літератури. Шандор Бонкало був призначений викладачем кафедри і залишався на цій посаді до 1924 року. Після Другої світової війни став 
професором кафедри української мови та літератури. ${ }^{1}$ Однак це призначення теж виявилося нетривалим (про причини див. LeBOVICs 2009: 156-161). Окрім циклу дисциплін української та русинської філології, Шандор Бонкало викладав історію російської літератури та російський фольклор (KISS 1995: 50-53). У квітні 1950 року його відправили на пенсію, аргументуючи тим, що нібито зневажливо говорив про Радянський Союз та його керівників.

Аттіла Шалга, дослідник діяльності Шандора Бонкала, наголошує, що навіть після 1990 року ім'я вченого не згадували в угорських виданнях, хоча відомо, що між двома світовими війнами він був єдиним дослідником української та російської літератури в Угорщині, у тому числі й закарпатської, i, поки мав можливість, викладав українську та російську мови (SALGA 1996: 131). Аттіла Шалга віднайшов документ від 6 лютого 1946 року, у якому Бонкало повідомляв про свої наукові плани, а саме такі: 1) виявити гунгаризми в писемних пам'ятках, творах художньої літератури, а також у закарпатських, галицьких та буковинських говорах (робота майже закінчена); 2) написати історію української літератури (більшість матеріалу вже зібрано); 3) у Національному музеї Угорщини зберігається близько 20 церковних служебників, повчань тощо, написаних церковнослов'янською мовою. У цих книгах $\epsilon$ безліч записів закарпатським українським говором. Бонкало мав на меті проаналізувати ці матеріали з точки зору їх мовної специфіки і надрукувати результати своїх досліджень у славістичних журналах (SALGA 1996: 132).

Як бачимо, Шандор Бонкало досліджував перш за все діалектологію, етнографію, культурологію сучасного Закарпаття (колишньої Підкарпатської Русі), історію української, русинської та російської літератур. В Енциклопедії українознавства слушно вказано: «Бонкало - філолог, фахівець із закарпатських українських говірок і літератури...» (Куьійович 1993: 157, див. ще ДзЕндзЕЛІвський 2007: 56). Про долю українців та української мови не раз ідеться в дослідженнях Шандора Бонкала. Зокрема, представлено місця проживання українців, їх чисельність у Росії, Галичині, Буковині та в Угорщині, висвітлено проблеми віросповідання, стан народної освіти, вказано на самостійність української мови порівняно з російською, згадано заборони і утиски щодо використання української мови з боку Росії. Автор пише і про тих русинів, які проживають на території колишніх Марамороського, Березького, Угочанського, Ужанського, Земплінського, Шарошського та Спішського комітатів Угорщини (BONKÁLÓ 1915: 67-79).

Побут гуцулів, їх говір постійно перебували в колі наукових зацікавлень Шандора Бонкала. Адже і сам науковець народився та виріс у гуцульському оточенні, був обізнаний із традиціями і звичаями своїх краян. Після переселення до Будапешта неодноразово бував у рідному краї, спілкувався із земляками. Із результатами своїх розвідок знайомив науковців, вважаючи цю справу потрібною тому, що «це цікаве плем'я, яке відрізняється від інших

\footnotetext{
${ }^{1}$ Про історію започаткування русинської мови та літератури в Будапештському університеті та призначення Шандора Бонкала викладачем русинської мови та літератури йдеться у статті В. Лебович (LeBovics 2017: 129-132).
} 
малоросів не тільки зовнішністю, звичаями, а й мовою, та й мову гуцулів ще ніхто не досліджував» (BONKÁLÓ 1911: 200). В іншій праці представлено життя, зовнішність, побут і звичаї гуцулів (BonKÁLó 1940: 74-83). Бонкало пише, що гуцули є найменшим і найціннішим плем'ям русинів. У праці згадується, що мова і побут гуцулів значно відрізняються від інших слов'янських народів. Ця відмінність, на думку Бонкала, утворилася частково завдяки географічному розташуванню території їх проживання, а частково - через тривалий зв'язок із румунами та угорцями.

Ось такі чи не перші детальні відомості про життя і побут гуцулів отримав угорський читач. Цій інформації передувала опублікована Ш. Бонкалом гуцульська народна казка, занотована фонетично, латиникою, гуцульським говором разом з їі угорським перекладом (BoNKÁLÓ 1911: 197-201). Збирач матеріалу наголосив, що казку записано від корінного жителя Рахова, який ніколи не покидав свій край, тож його мовлення не зазнало впливу неологізмів (BonKÁLó 1911: 201), а отже, і відбиває стан давньої гуцульської говірки.

У своїх мовознавчих працях Бонкало аналізує гуцульські говори. На прикладах доводить, що гуцульський говір зберіг праслов'янську форму зворотного займенника sę, який приєднується безпосередньо до дієслова в тому випадку, якщо хоче виділити його (тобто дієслово) (Účenyk u škúl'i účytśë), або стоїть на початку речення (Ne svarýśë z námy) (BonKÁLÓ 1912: 41-43).

У 1910 році вийшла друком дисертація Шандора Бонкала (див. BoNKÁLÓ 1910) написана під керівництвом відомого угорського славіста Оскара Ашбота (1852-1920), який написав рецензію на цю роботу (Аsво́тн 1911). У вступі лінгвіст наголошує, що українська мова (русинська - за тодішньою термінологією, вживаною автором), якою розмовляють на Буковині, в Галичині і в північно-східній частині Угорщини малодосліджена, незважаючи на те, що «ця мова вже не terra incognita для мовознавців» (BonkÁló 1910: 4). Тут перераховано більшість наукових праць, у яких порушено проблеми русинської мови. Однак варто зауважити, що Бонкало не згадав «Русько-мадярский словарь» Ласло Чопея, у передмові якого укладач подає детальну характеристику русинської мови, описує їі особливості в зіставленні зі старослов'янською та російською, аналізує особливості їі морфології (ЧоПЕй 1883: VIIIXLVI). Автор слушно зауважує, що в рахівському говорі є безліч іншомовних елементів, а саме запозичень із польської, румунської, пізніше 3 німецької та угорської мов (подається кілька тематичних груп) (BoNKÁLó 1910: 1112). Іншомовний вплив простежується і на рівні фонетики та синтаксису. За припущенням автора, у XVI столітті територія Рахова була ще не заселена. Самі гуцули про своє минуле нічого не знали: «та прийшов дідо десь із битангів, але бізівно нічо не знаю», - так висловлювалися вони (BoNKÁLÓ 1910: 7). На цю територію почали прибувати люди лише в кінці XVII - на початку XVIII століття з сусідньої Галичини (пізніше поселено німців, поляків, євреїв та угорців). Себе місцеві жителі називають руснаками, а сусіди їх кличуть гуцулами. Спілкуються своєрідною говіркою, яка утворює закриту систему, однак більшість із них знають також німецьку та угорську мови. Зауваження 
Бонкала щодо пристосування іншомовних слів досить однобічне: «іншомовні слова адаптуються за допомогою суфікса -ка та -ик». Щоб довести це твердження він наводить декілька прикладів: тегерка 'вантажний потяг' < уг. tehervonat; вештлик 'безрукавка' < нім. Weste (BonKÁLó 1910: 12-13). Бонкало зауважив, що гуцули довгий час були неписемними, отже, через відсутність писемних пам'яток, історичне порівняння їхньої мови провести неможливо. У роботі подається також карта поселень, у яких побутує гуцульський говір.

Другий розділ присвячений опису фонетики рахівського гуцульського говору. Автор зауважує, що найчастіше у досліджуваному ним говорі вживається голосний $i$, другий найбільш уживаний $y$ (и), пізніше сюди відносить також голосний ё (BoNKÁLÓ 1910: 15-17). Рецензент Оскар Ашбот вважає це припущення сумнівним, бо навіть у казці, записаній Бонкалом, він підрахував, що найчастіше вживається голосний $a$ (305 разів), а голосний $i$ тільки 100 разів. Однак зазначає, що на основі однієї казки судити не варто (Аsво́тн 1911: 226-227). Згідно зі спостереженнями Бонкала у мовленні неосвічених жителів Рахова, які ніколи не бували за межами рідного краю, після палатальних на місці голосного $а$ вживається голосний ё: findžё 'чарка', kúchńë 'кухня', lóšë ‘лоша' (BonkÁló 1910: 16). Правила наголошення в цій говірці такі ж, як в українській мові в цілому, однак часто простежується вплив угорського наголошування (на першому складі), наприклад, béfel 'наказ', нім. Befehl. Наведено приклади давньої рефлексації $(j) i<\breve{e}$. Доведено, що в гуцульських говорах слід розрізняти три типи голосного $e: 1)$ «звичайний»; 2) у позиції біля палатального завжди більш закритий, ніж в інших позиціях (однак різниці у передачі «звичайного» голосного $e$ i більш закритого не робить); 3) «дуже закритий e», який позначає літерою ё; голосний $y$ (и), вживається на місці давніх $y$ та $i$. Автор зауважує, що система консонантизму має небагато відхилень від фонетичних норм української мови. Цікавим $є$ твердження Бонкала, що в гуцульському говорі існує багато скорочених форм, наприклад: móž замість móžeš; chóč замість chóčeš. У кличному відмінку вживається переважно скорочення: brá замість bráte; chló замість chlópe; Yvá замість Yváne; Pe замість Petre. Часте використання скорочених форм звертань Бонкало пояснює причиною віддаленого проживання гуцулів одне від одного, а під час спілкування окриками на далеку відстань чутно лише частину слова (BonKÁLó 1910: 46). Автор також робить спробу зіставити галицькобуковинський і рахівський говори, ось деякі його висновки: у рахівському говорі сполученню с́ё відповідає галицько-буковинське ća: molodýce - molo$d y ́ c a$; у галицько-буковинському говорі деколи замінюють звук $\dot{s}$ на звук $\dot{c}$ : śeśa žínkå і ća žínkå, а в Рахові завжди кажуть seśë žínkå; у рахівському говоpi голосний $e$ у наголошеному і ненаголошеному складі ніколи не зміниться на голосний $a$, як це буває в галицько-буковинському говорі, наприклад, $d o$ cárkvy do cérkvy; mané mené. Автор зауважує, що найбільша різниця між галицько-буковинським і рахівським говорами простежується на рівні лексики. На останніх двох сторінках подаються гуцульські пісні та невеличке оповідання (теж у записі сторічної давності). 
В окремій статті Шандор Бонкало доводить самостійність української мови, аргументуючи це твердження особливостями фонетики, лексики, морфології та синтаксису (BONKÁLó 1914: 87-110). Він розширив відомості свого попередника Ласлова Чопея про особливості української мови у зіставленні з великоруською, відкидаючи хибну точку зору тих мовознавців, які вважали, що малоруська мова $є$ діалектом великоруської. Для підтвердження своєї позиції науковець наводить безліч аргументів: представив результати історичних змін у процесі формування української мови, відмінних від російської; наголосив на особливостях фонетичної, морфологічної та синтаксичної систем аналізованої мови; навів приклади слів, несхожих у двох мовах (щоправда, угорський читач відмінностей не бачить, тому що приклади подано угорською без вказівки українського та російського відповідника) (BoNKÁLÓ 1914: 104-107). Українська мова, за тлумаченням Бонкала, $є$ народною мовою українців. Про окремішність української мови свідчить і той факт, що нею перекладено Святе Письмо (Пересопницьке Свангеліє 1556-1561р.). Бонкало наголошує на важливості діяльності Івана Котляревського і Тараса Шевченка в аспекті становлення літературної мови. Водночас зауважує: «Російський уряд робить усе можливе для того, щоб світ знав про існування лише російського народу та його мови, існування ж русинського народу та його мови вони замовчують» (BONKÁLÓ 1914: 107). Бонкало підкреслює заслуги С. СмальСтоцького та Т. Гартнера у створенні граматики української мови, указує на хибність думок авторів у трактуванні походження української мови (SMALStOCKYJ-GARTNER 1913). Автор статті констатує, що українська мова розвивалася окремо від російської тому, що «русини не належать до Російської імперії, вони не перебувають під політичним, культурним та економічним впливом Москви, тому і русинська мова не могла зазнати впливу московської мови» (BonKÁLó 1914: 102). Русинська література через несприятливі політичні чинники (заборони, утиски) не мала можливості досягнути високого рівня. Однак вона розквітає в Галичині завдяки діяльності Юрія Федьковича, Івана Франка, Ольги Кобилянської. Заслугою Ш. Бонкала є те, що саме він свого часу інформував угорську наукову еліту про статус української мови, що має право функціонувати в якості літературної мови українського народу, належно оцінив ії місце серед інших слов'янських мов.

В іншій праці автор наголошує, що підкарпатські русини генетично належать до української (русинської, малоруської) гілки східнослов'янського народу (BoNKÁLÓ 1935: 11). Через географічні чинники русини не мали зв'язків із одноплемінниками по той бік Карпат упродовж століть. 3 огляду на віддаленість від своїх братів, що живуть у Росії та Польщі, створена русинами література має свої специфічні особливості.

Закарпатську русинську літературу Бонкало поділяє на чотири періоди:

1) доба писемних пам'яток від початку до кінця XVI століття;

2) доба національної літератури від кінця XVI ст. до кінця XVIII ст.;

3) доба занепаду від кінця XVIII ст. до 1920 року;

4) доба пошуків від 1920 року до сьогодення (тобто до 1935 року). 
Покликаючись на праці Є. Фенцика, Е. Сабова, В. Бірчака та Ф. Тіхого, Бонкало зазначає, що до другої половини XVI ст. підкарпатські русини не мали власних духовних надбань, а їх духовні потреби задовільняли церковні книги великоруської та сербської редакцій, привезені з Галичини. Національна русинська література бере свій початок 3 появи реформації. Долишняцькі, шарошські та спішські русини перейняли від протестантів вчення, згідно з яким Святе Письмо люди повинні розуміти, отже, Слово Боже потрібно проповідувати мовою народу. Бонкало відхиляє припущення своїх попередників про створені на території Підкарпаття писемні пам'ятки (BONKÁLó 1935: 14-16), стверджуючи, що до кінця XVI століття русини не мали і не могли мати власної літератури. Вони не мали можливості здобувати освіту, оскільки перша початкова школа була відкрита в Мукачеві 1681 року з метою навчання майбутніх священиків (BoNKÁLó 1935: 18). Розвиток шкільництва особливо посилився після прийняття унії. Перші Свангелія, завезені з Польщі, місцеві русини переписували на свій лад, використовуючи й угорські відповідники текстів. Пояснення з Свангелій зазвичай були «вільними переробками», тому ці праці, на думку Бонкала, деякою мірою є оригінальними. Писарі вільно подавали навіть тексти Святого Письма. На жаль, більшість цих рукописів було знищено через недбалість нащадків - греко-католицьких попів (BONKÁLó 1935: 21-22).

У XVII-XVIII століттях біблійні повчання були найпоширенішими. 3 позиції мовознавства та змісту творів, на думку Бонкала, найціннішими $є$ рукописи, написані на південно-західній частині Мараморощини. Найбільшої уваги автор приділяє пам'яткам, відомим під назвами «Нягівські повчання на Свангелія» та «Углянський ключ» (BoNKÁLÓ 1935: 22-24, 27-29). Наголошує на важливості творчого доробку Михайла Оросвиговського (Андрелли), однак вважає його «фанатиком з вузьким світоглядом» (BONKÁLÓ 1935: 3233). Він упевнений, що Оросвиговський був добре обізнаний з угорською полемічною літературою, адже у своєму тритомному Tractatus contra latinos et graeco Catholicos (1672-1681) використовує безліч цитат та слів з угорської мови. Найулюбленішим твором русинів, на думку Бонкала, є роман «Александрія» про Олександра Македонського, який потрапив до Підкарпаття через Галичину з південної Росії. Авторові відомо п'ять переписів (редакцій) роману, виконаних на Закарпатті. Бонкало згадує про Гукливський літопис, написаний частково латинською, частково русинською мовою і виданий 1907 року Гіадором Стрипським. Окремий розділ він присвячує огляду підкарпатської поезії XVII-XVIII століття, покликаючись на видання Володимира Гнатюка «Угро-руські духовні вірші», яке містить у собі близько трьохсот церковних пісень (BONKÁLÓ 1935: 37-38).

У XVII-XVIII століттях народна рукописна література була доволі багатою і строкатою. Однак у цей період «навчали тільки попів, а не народ», узагальнює Бонкало (BONKÁLÓ 1935: 40), адже уніатські священики писали латинською або ж церковнослов'янською, тому ці твори народ не розумів. Греко-католицький єпископ Мукачівської єпархії Й. де Камеліс написав для 
своїх вихованців катехизис латинською, перекладений церковнослов'янською галицьким священиком Іваном Корницьким, що одержав назву «Катехизис для науки Угроруським людям» (1698 р.). Це перша друкована книга підкарпатських русинів. Бонкало наголошує, що на Підкарпатті в той час не було священиків, які могли б перекласти книги з латинської. Спископ Мануїл Ольшавський сприяв олатиненню уніатського духівництва. Народна мова була відсторонена. Щоб виправити становище, єпископ Брадач написав і видав перший буквар, який через виявлення в ньому схизми було знищено цензурою. Мова і стиль посібника «Катехизм» Іоана Кутки 1803 року були незрозумілими для учнів через надмірне вживання одночасно слів церковнослов'янських, російських та русинських із застосуванням слов'янського та латинського синтаксису (BoNKÁLÓ 1935: 42). Однак посібником користувалися до кінця ХІХ століття.

Період з кінця XVIII століття до 1920 року Бонкало називає періодом занепаду. Духовну відсталість русинів дослідник пояснює ще й тим, що талановиті сини цього регіону збагачували культуру інших слов'янських народів або угорців (ВоNKÁLó 1935: 42-51). Русинська інтелігенція не розуміла великоруську літературу, з якою зблизити їх намагався русофіл Адольф Добрянський. Найвідданішим апостолом русофільства Бонкало вважає Івана Раковського, автора першої російської граматики, написаної угорською мовою (Ужгород, 1867 р.). Він переконаний, що завдяки сприянню Добрянського і Раковського найвидатніший поет закарпатських русинів Олександр Духнович також перейшов на русофільські позиції. Попри наївність, автор високо оцінює діяльність Духновича в галузі розвитку культури русинів (BonkÁLÓ 1935: 47-51), адже Духнович довів, що мова, якою писали закарпатські русинські священики у XVII-XVIII ст., придатна для написання підручників, творів художньої літератури тощо.

Шандор Бонкало наголошує, що видані Обществом св. Василія Великого газети були непридатними для читання через надмірне вживання російських слів, тому читачі вимагали, щоб у газетах писали мовою, зрозумілою для них. Бонкало аналізує літературну діяльність членів «общества» (BonKÁLÓ 1935: 53-58), а саме: І. Раковського, А. Добрянського, А. Кралицького, С. Фенцика, І. Сільвая, О. Митрака та Ю. Ставровського-Попрадова. Наявність русофільської орієнтації в літературі, на думку Ш. Бонкала, призвела до повного краху: «мало хто розумів їі, тому і не читали» (BonKÁLó 1935: 58). А в системі шкільної освіти викладання церковнослов'янської та російської мов не дало позитивних результатів. Видання членів Общества св. Василія Великого Бонкало вважає «мертвим скарбом невідомого походження», які не збагатили ані російську, ані русинську літературу (BonkÁLÓ 1935: 59).

Духовну відсталість закарпатських русинів Бонкало вбачав у тому, що вони не розуміли своїх священиків і вчителів, не могли впоратися 3 труднощами церковнослов'янської та російської мови. Міністерство релігії та народної освіти Угорщини вважало за необхідне створення підручників русинською мовою. Однак укладений Ласло Чопеєм підручник за змістом був 
далекий від потреб учнів. Автор дав високу оцінку діяльності Августина Волошина та Юрія Жатковича, їх внескові у розвиток русинської літератури, культури та створення підручників русинською мовою.

Бонкало переконаний, що після Першої Світової війни русинська література все ще залишалася на початковому етапі свого розвитку. Тому українофільська орієнтація досить швидко вплелася в діяльність русинофілів, хоч перебувала в гострому протиріччі з русофільством. Русинська орієнтація була повністю витіснена. Підтримана українськими емігрантами, українська орієнтація зацікавила Августина Волошина, Юлія Бращайка та інших, отож вони перейшли на бік українофільства, створивши товариство «Просвіта» (BonKÁló 1935: 61-64). Творчість Василя Гренджі-Донського Бонкало оцінив дуже високо (БонкАЛо 1935: 66-68), коли назвав його «першим справжнім русинським поетом закарпатців». Таке ж визнання здобула і творчість Юлія Боршоша-Кум’ятського (BoNKÁLÓ 1935: 68-70). Бонкало переконаний, що представники русофільської орієнтації відійшли від дійсності, жили в світлі мрій. Завершив свою працю науковець так: «Борються між собою три різні орієнтації. Яка з них переможе, наразі невідомо, адже це питання скоріш за все політичне, а не літературне» (BonkÁLÓ 1935: 77).

Хрестоматія Ш. Бонкала побачила світ 1919 року в Будапешті - під назвою «Виімки из угро-руського письменства XVII-XVIII вв.» (РАхІвський $1919){ }^{2}$ У передньому слові укладач пише про популярність рукописів, написаних народною мовою на Підкарпатті у XVII-XVIII століттях з метою використання їх для навчання школярів. Бонкало пропонує уривки із шістнадцяти пам'яток для тимчасового користування учням (серед пропонованих текстів є уривок із дарчої грамоти селянина Улашина Мстичівському монастирю, дарчої грамоти Марії Вараді, Гукливського літопису, урбарій, уривок Даниловського учительського євангелія середини XVII ст., збірника Тесловцьового попа Степана, Нягівських повчань на Свангеліє та ін.). Укладач черпав матеріали з видань Євменія Сабова, Гіадора Стрипського, Олександра Петрова та Івана Франка (перелік див. у передньому слові). Ю. А. Яворський у виданні 1930 року, присвяченому президенту Томашу Масарику, різко критикував цей доробок Бонкала, зазначивши, що «тексти самі по собі видані незадовільно і недбало, містять грубі друкарські помилки» (Яворскій 1930: 87), тому для шкільного користування він їх не рекомендує.

Шандор Бонкало першим привернув увагу дослідників до того, що в мові русинської літератури наявні угорські лексичні елементи (BoNKÁLÓ 1934). Зазначив, що полемічна література, повчання, вірші та прозові твори, написані народною мовою, містять безліч слів з угорської; автори часто використовують довгі цитати угорською або ж у русинському перекладі. Автор констатує, що найбільше угорських вкраплень закріпилося в русинській мові саме в XIV-XVII ст. Однак сам собі суперечить, коли в іншому виданні зазначає:

${ }^{2}$ Шандор Бонкало підписався псевдонімом О. Рахівський. Для сучасників ідентифікація особи укладача була очевидною (див. ЛЕЛЕКАЧъ-ГАРАЙДА 1944: 182). 
«найбільше угорських слів потрапило до русинської мови в XVII-XVIII ст.» (BoNKÁLÓ 1940: 112). Вiн переконаний, що жоден тодішній твір не має особливої літературної чи наукової цінності, але «з позиції угорсько-русинських міжмовних контактів вони надзвичайно важливі» (BONKÁLó 1940: 43). До прикладу подає кілька цікавих кальок з угорської: szomárstkij kásély = уг. szamárköhögés (укр. кашель); pantlikova hliszta = уг. pántlikás giliszta (укр. глисти); domovoj zajac = уг. házinyúl (укр. кролик); ja takzse tak chodil = уг. én is úgy jártam (укр. зі мною теж так трапилося); szerencsu probáloval < уг. szerencsét próbált (укр. шукав щзастя) та ін. У статті представлено усього кілька запозичених слів та виразів з угорської, однак своїми науковими порадами Бонкало закликав до подальших досліджень мову писемних пам'яток.

В іншій статті Бонкало аналізує 23 гунгаризми, до яких додає фонетичні варіанти та лінгвогеографічні дані, а також наголос та форму родового відмінка однини, серед них такі слова: báus < bajusz 'вуса'; bend'úch < bendö 'пузо'; bokréjda (pokréjta) < bokréta 'букет'; bokor < bokor 'пліт'; bosórka < boszorka, boszorkány 'відьма'; darába < darab 'шматок' і в значенні 'пліт'; fáj < fáj 'болить'; gal'ír < gallér 'комір'; kájła < kajla 'кривий’; káłap < kalap 'капелюx’ (BonkÁLÓ 1916: 465). Автор переконаний, що у мові русинів налічується близько 2000 угорських лексичних елементів.

Проаналізувавши мовознавчі праці Шандора Бонкала, а також ті, у яких представлено писемні пам'ятки, можемо стверджувати, що дослідник своїми науковими розвідками вніс неабиякий вклад у розвиток науки про українську мову, діалектологію, у тому числі і гуцульську. Результатами своїх досліджень інформував широке коло угорських науковців про життя українців, їхню мову, історію, етнографію, а також історію закарпатської літератури та культури.

\section{Література}

ГЕРАСИМОВА 2003 = ГЕРАСИМОВА Г. П. Бонкало Шандор. В кн.: Енциклопедія історії України. Т. 1. Київ, 2003. 338.

ДЗЕНДЗЕЛІВСьКИЙ $2007=$ ДЗЕНДЕЛІВСьКИЙ Й. О. Бонкало Олександр Олександрович. В кн.: Українська мова. Енциклопедія. Київ, 2007. 56.

Куьй̆ович 1993 = КуБाйович В. Бонкало Олександер. В кн.: КуБाйович В. (ред.). Eнцчиклопедія українознавства. Т. 1. Львів, 1993. 157.

ЛЕЛЕКАЧъ-ГАРАЙДА 1944 = ЛЕЛЕКАЧъ Н., ГАРАЙДА И. Загальна библіографія Подкарnamя I. / LELEKÁCS Miklós, HARAJDA János: Kárpátalja általános bibliográfiája 1. Ungvár, 1944. [Факсимільне видання: Ужгород, 2000.]

Поп 2001 = Поп Иван: Бонкало Александр. В кн.: Поп Иван (ред.): Энцииклопедия Подкарпатской Руси. Ужгород, 2001. 101-102.

РАХІвський 1919 = РАХІвський О. Виімки из угро-руського письменства XVII-XVIII Bв. Budapest, 1919.

ЧоПЕй 1883 = CSOPEY László: Rutén-magyar szótár / Русько-мадярский словарь. Budapest, 1883. 
ЯвоРскій 1930 = ЯвоРскій Ю. А. Литературные отголоски «русько-краинского» періода въ Закарпатской Руси 1919 года. В кн.: Карпаторусскій сборникъ. Подкарпатская Русь. Въ честь президента Т. Г. Масарика (1850-1930). Ужгородъ, 1930. 79-87.

Asвóтн 1911 = Asвóтн Oszkár: Bonkáló Sándor: A rahói kisorosz nyelvjárás leíró hangtana [Описова фонетика рахівської малоруської говірки]. Gyöngyös, 1910. Nyelvtudomány 3 (1910-1911): 224-240.

BONKÁLÓ 1910 = BONKÁLó Sándor: A rahói kisorosz nyelvjárás leiró hangtana [Описова фонетика рахівської малоруської говірки]. Gyöngyös, 1910.

BoNKÁLÓ 1911 = BonKÁLó Sándor: Huczul népmese [Гуцульська народна казка]. Nyelvtudomány 3 (1910-1911): 197-201.

BonKÁló 1912 = BonKÁLó Sándor: A sę refl. a huczul-kisoroszban [Зворотний займенник sę в гуцульському говорі малоруської мови]. Nyelvtudomány 4 (1912-1913): 41-43.

BONKÁLÓ 1914 = BonKÁló Sándor: Az orosz (nagyorosz) és a rutén (kisorosz vagy ukrajnai) irodalmi nyelv kérdéséhez [До питання руської (великоруської) та рутенської (малоруської або української) літературної мови]. Nyelvtudomány 5 (1914-1915): 81-110.

BonkÁló 1915 = BonkÁLó Sándor: A szlávok [Слов’яни]. Budapest, 1915.

BoNKÁLÓ 1916= BonKÁLó Sándor: Beiträge zur ukrainischen Wortforschung [Дані до дослідження української лексики]. Archiv für Slavische Philologie 36 (1916): 464-475.

BONKÁLÓ 1934 = BONKÁLÓ Sándor: Magyar elemek a rutén irodalomban [Угорські елементи в рутенській літературі]. In: BEKE Ödön, BENEDEK Marcell, TuRócZI-TrostLeR József (szerk.): Emlékkönyv Balassa Józsefnek. Budapest, 1934. 42-45.

BonkÁLó 1935 = BonkÁLó Sándor: A kárpátalji rutén irodalom és müvelődés [Підкарпатська рутенська література і культура]. Pécs, 1935.

BonKÁló 1940 = BonkÁló Sándor: A rutének (ruszinok) [Рутени (русини)]. Budapest, 1940.

BonKÁLÓ 1996 = BonKÁló Ervin: Bonkáló Sándor életrajza [Життя Шандора Бонкала]. In: BonkÁLó Sándor: A rutének (ruszinok). 2. bőv. kiad. Basel-Budapest, 1996. 7-12.

KIss 1995 = KIss Kálmán: A magyarországi orosznyelv-oktatás első korszaka (1849-1949) [Перший етап у вивченні російської мови в Угорщині]. Debrecen, 1995.

LeBOVICS 2009 = LeBOVICS Viktória: История украинистики в Будапештском университете. Studia Russica XXIII. Budapest, 2009. 156-169.

LEBOVICs 2017 = LEBOVICS Viktória: Bonkáló Sándor és az ukrán szak története Budapesten [Шандор Бонкало та історія української філології в Будапешті]. In: CseHILY József, VÉGVÁRI Valentyina, WoŁosz Robert (szerk.): „A magyar-szláv kapcsolatok: múlt és jelen" címü nemzetközi tudományos konferencia tanulmánykötete (Pécs, 2016. október 13-14.). Pécs, 2017. 129-136.

SAlga 1975 = SAlgA Attila: Bonkáló Sándor és a keleti szlávok [Шандор Бонкало і східні слов'яни]. Bölcsészdoktori disszertáció. Eger, 1975.

SALgA 1996 = SALgA Attila: Utószó. Bonkáló Sándor munkásságáról [Післямова. Про діяльність Шандора Бонкала]. In: BonKÁLó Sándor: A rutének (ruszinok). 2. bőv. kiad. Basel-Budapest, 1996. 131-169.

SMAL-Stockyj-GARTNER 1913 = SMAL-Stockyj Stephan von, GARTNer Theodor: Grammatik der ruthenischen (ukraïnischen) Sprache. Wien, 1913. 